\title{
MAIN DIFFICULTIES IN TRANSLATING CONTRACTUAL DOCUMENTATION (ENGLISH/RUSSIAN)
}

\author{
Lilia Timofeeva, Maria Morozova, Tamara Potapova
}

St Petersburg University, School of Foreign Languages,

Department of the English Language for Business and Law, Russia

\begin{abstract}
The article is devoted to one of the most common translation problems in the sphere of law, namely finding the adequate equivalents in vocabulary, especially it concerns foreign terminology, in grammar and in text structure.

While it is well-known that equivalence is one of the key concepts in translation, the research on practical applications of this principle in different professional spheres is still limited. With the rise of the interest to the machine translation, the special attention to the most common translation problems in the sphere of law can contribute to the overall understanding of the translation process. The methodological approach taken in this study is a mixed methodology based on comparative, structural, socio-linguistic and socio-cultural aspects of translation. The material presented in the article is based on the original contracts developed in English and Russian for the major oil and gas projects to be implemented in Russia 2006-2009. The examples of vocabulary, grammar and text structures equivalents can show the reasons for emergence of the main translation difficulties - polysemantic structure of some terms, absence of concept in either language, dependence of the meaning of the term on the context, idiomatic expressions, historically established traditions in legal text formation - emphasizing the idea that equivalence principle should be considered as a priority when translating contractual documentation.
\end{abstract}

Key words: translation, adequacy, equivalency of translation, professional language, terminology, document structure, preamble

\section{INTRODUCTION}

For the last decades due to the growth of globalization processes and the development of international collaboration the role of legal texts is increasing in connection with the intensive development of world markets.

A lot of linguistic researches both in Russia and abroad single out a special system of linguistic means catering for communication in law, i.e. legal language. However, the legal language is not homogeneous and includes various types of discourses. The BerlinBranderburg Academy of Science research group for the legal language isolates even "the language norm in law, i.e. the regulations imposed on arguments in court, on legal translations, issues of linguistic signs"(Alimov,2005).

Submitted January $25^{\text {th }}, 2021$, accepted for publication March $5^{\text {th }}, 2021$

Corresponding author: Lilia Timofeeva. St Petersburg University, School of Foreign Languages,

Department of the English Language for Business and Law, Russia|E-mail: lilytimofeyeva@yahoo.com 
Legal English is mainly about writing. As Bryan Garner (Editor in Chief of Black's Law Dictionary and expert in Legal English) said, " $90 \%$ of a lawyer's job is to write"1. So, we should imagine that the translator in the field of law would deal mainly with the written form of the legal language, various types of legal documents, including contracts. The translation of legal documents is regarded to be extremely challenging.

A famous German lawyer E. Rabel once said that in the process of comparative studies of different legal systems and acquiring the legal language one will inevitably face numerous problems connected with the necessity to convey the content of the legal text in one language into the other one maintaining the grammatical norms of the other (Fedorov,2002). Obviously, while translating the translator faces traditional problems connected polysemantic structure of some terms, absence of concept in either language, dependence of the meaning of the term on the context, idiomatic expressions.

In addition to the specificity of legal language and legal terminology, the differences between common and civil law systems provides some particular problems. As regards the challenges, Baker (Baker,1992) mentioned that the lack of verbal or functional equivalence in the target language is one of problems that faces legal translators, while Gyde Hansen (Hansen,2017) said that the translator's lack of knowledge of the modern theories and strategies of legal translation causes mistakes and problems in translation.

Also traditions in constructing legal documents, peculiar for every national legal system can be a problem. As an illustration - even if we are translating a legal document from Russian into English, we have to consider what variant of English and what legal system we are dealing with: UK English, or Welsh, or Scottish, or the USA one.

The review of literature on the problems of legal translation shows the majority of researchers consider the terminology, and translation of lexical units without connection with the text, context and situation of communication to be among the most typical ones (Levitan, 2015). The main difficulty in legal translation lies in the fact that translation of legal terminology means translation of one legal system into the other one. It is based on the fact that law is deeply imbedded into the national system of culture. And as a result we notice differences even in law systems of countries belonging to one and the same legal family (Pankratova, 2003). Some researchers state that these differences are the main cause of translation difficulties, all other ones being of a lesser scale. They stress the postulate that it is unacceptable to translate realities of one country with realities of the other (Alekseeva, 2014).

The aim of this article is to develop an understanding of the most typical problems in translation (on the example of legal documents) and the most widely used ways of translation, Being interpretative in nature it shows the difficulties a translator may face working with the legal documents and discusses possible solutions within the frames of, socio-linguistic and socio-cultural domains. The authors also give some practical guidelines for teaching legal translation.

\footnotetext{
${ }^{1}$ https://writtenlegalenglish.com/2019/08/05/what-is-legal-english/
} 


\section{TO THE TRANSLATION THEORY}

Translation in contrast to other ways of language interaction is employed for providing a rightful replacement of the original, moreover this replacement obtained in the process of translation is considered identical to the original text. Notwithstanding the fact, that to reach absolute identity in the process of translation is impossible, as losses are inevitable, due to differences in grammar, lexical and phonetic peculiarities of the original language and the language of the translation, together with the dissimilarities in cultures, history, background knowledge, specific features in reflecting the reality.

As it was mentioned above, there is no identity between the content of the original and the translation, the notion of equivalency was introduced, which may be interpreted as a notional proximity between the original and the translation. As it is extremely important to reach maximum congruence between these texts, the problem of equivalency of translation in general, and legal translation in particular becomes one of the most important and evident problems.

Nowadays the modern theory of translation comprises various approaches to the definition of equivalency. Some scientists insist on the necessity of including the condition of equivalency into the very notion of translation. For example, J. Katford, an English specialist in the theory of translation understands translation as "exchanging one text material in one language for an equivalent text material in another language" (Katford, 1978). Also, an American linguist E. Nida points out that translation means creating "the closest natural equivalent to the original" in the language of translation (Nida,1964).

All linguists specializing in the theory of translation state that the main criteria of an adequate translation (of a legal document in particular) are as such:

- Accuracy - all facts presented in the original should be stated in the translation;

- Conciseness - all facts presented in the original should be translated in a compact and laconic way;

- Clarity - concise and laconic translation should not hinder the fullness of the translation of the lexical units of the original;

- Literary character of translation - the text of the translation should answer all norms of the literary language, without the usage of syntactical constructions of the language of the original (Bazilev, 2000). In modern studies on the theory of translation one may find the terms - equivalency and adequacy of translation. Sometimes they are viewed as synonyms, sometimes they are considered to have different meaning. For example, in the article of R. Levitsky "To the principle of functional adequacy of translation"(Levitsky, 19884), whereas other authors differentiate these terms.

One of the most well-known specialists in the theory of translation, V. N. Komissarov, claims that equivalency and adequacy of translation are non-identical but closely related notions. He stated that adequate translation is broader in meaning than equivalent translation. Adequate translation is good translation, as it provides communication in full. Equivalent translation is the translation providing the semantic identity of the target and source texts. Two texts may be equivalent in meaning but not adequate (for example the original and the translation may differ in style, expressiveness , etc.) (Komissarov, 2002).

Another linguist - A. Shveitser - differentiates these terms as referring to two aspects of translation: translation as result and translation as process. He believes that we can speak of equivalent translation when we characterize the end-point (result) of translation, as we compare whether the translated text corresponds to the original text. Adequacy 
characterizes the process of translation. The translator aims at choosing the dominant text function, decides what $\mathrm{s} / \mathrm{he}$ can sacrifice. Thus, adequate translation is the translation corresponding to the communicative situation (Shveitser, 1989).

Close to this understanding of translation adequacy is E. Nida's concept of dynamic equivalence, "aimed at complete naturalness of expression" and trying "to relate the receptor to modes of behavior relevant within the context of his own culture". Nida's principle of dynamic equivalence is widely referred to as the principle of similar or equivalent response or effect (Nida, 2004).

Y. Retsker states that the notion of adequate translation comprises that of equivalent. According to him, an adequate target text describes the same reality as does the source text and at the same time it produces the same effect upon the receptor (Retsker, 1982).

We share the views of V. N. Komissarov on relations between the notions of adequacy and equivalence, as well as his views on existence of levels of equivalency together with his idea of paying much attention to particular circumstances of communication, which plays a vital role in establishing the level of equivalency.

According to Komissarov the relations of equivalency between corresponding levels of original and translation are being established in the process of translation. The studies of the levels of equivalency possess not only theoretical importance, but they are significant for practice of translation, as they allow to measure the degree of closeness to the original, which a translator may reach in the process of translation (Komissarov,1990). The problem is in detection and analysis of the degree of accuracy of rendering the content of the original text employing the means of another language. Traditionally we distinguish three types of translation: adequate, literal and free (Komissarov,1990).

\section{TYPES OF TRANSLATION}

Let us look at the types of translation more precisely. What do we understand under each type of translation?

Adequate translation is the translation which is conducted on a level, necessary and sufficient for rendering the content according to the norms of the language of translation. Literary translation is a word-for-word translation; it is of a lower level than an adequate one, as it allows various grammatical, lexical, stylistic and other types of violations of norms of the language of translation. Free translation is considered as a translation of a higher level regarding the level of word-for-word translation, which may be considered a reference point of evaluating the quality of translation. Free translation does not violate the norms of the language of translation, but its level of equivalency is not high enough. This is acceptable while translating fiction, but not acceptable in the case of technical and legal translation. Everyday practice shows that in translation of technical and legal texts the literary type of translation is mostly used. It ensures exact translation of terminology, which are in abundance in the texts of these kinds, but on the other hand, we should not forget that "the text of the translation never will be an absolute equivalent of the original text" (Katford,1978). This leads us to understanding that it is the adequate type of translation, which combines a high quality exact translation of terminology and professional vocabulary and follows the rules and norms of the Russian language as the language of translation, is the best type of translation. However, we also should mention that still we face certain difficulties in translation of legal texts. 
Let us look at peculiarities of legal texts which distinguish this kind of special translation.

Legal texts possess a lot of legal terms, which are translated into the Russian language as word combinations (remedy - средство судебной защиты SREDSTVO SUDEBNOY ZASHCHTI, deterrence - средство удержания устрашением от совершения преступных действий SREDSTVO UDERZHANIYA USTRASHENIEM OT SOVERSHENIYA PRESTUPNIKH DEYSTVIY, indictment - обвинительный акт OBVINITEKNIY AKT etc.)

The written and oral legal texts possess peculiar idiomatic and phraseological expressions which either are seldom or never used in general literary language to make default - I. не исполнять обязанности NE ISPOLNYAT' OBYAZANNOSTI, 2. не являться в суд NE YAVLYATSYA V SUD; Marshal of the court - судебный исполнитель SUDEBNIY ISPOLNITEL'; to meet claim - оспаривать иск OSPARIVYAT' ISK etc.).Also there is an abundance of elliptical constructions, strictly regulated usage of verbal forms and constructions, usage of Latin words and expressions (: mens геа - виновная воля VINOVNAYA VOLYA, вина VINA; stare decisis - обязывающая сила прецедентов OBYAZIVAYSHCHAYA SILA PRETSENDENTOV etc).

Legal texts exploit many abbreviations, many of which are used only in legal texts and documents: ALJ - Administrative Law Judge - судья административного суда SUD'YA ADMINISTRATIVNOGO SUDA; USJC — United States Judicial Code - кодекс законов США о судоустройстве KODEKS ZAKONOV SSHA O SUDOUSTROISTVE; CtApp - Court of Appeal - апелляционный суд APPELYATSIONNIY SUD etc.

Moreover while translating legal texts we should remember that every country not only possesses its own legal system but also its own legal terminology and realities: for example - город-графство GOROD-GRAFSTVO in England is County of city (of town), county - графство GRAFSTVO, a город GOROD - округ OKRUG in the USA - a metropolitan town; county - округ OKRUG, court of error - апелляционный суд APPELYATSIONNY SUD(in some states of the USA) etc.

But the core of translation is definitely correct translation of terminology which requires deep personal knowledge and in the case of difficulty professional dictionaries and glossaries.

Analysis of modern studies of ways of translation shows that we may single out the most popular ways of translation of legal terminology are transcription and transliteration, especially when terms contain personal names - LDC - Limited Duration Company Компания с ограниченным сроком - KOMPANYA S OGRANICHENNIM SROKOM, then we mention direct word for word translation - Queen's Counsel - Советник Короны SOVETNIK KORONI, a less popular joint method (when transliterationltranscription is used together with word for word translation) - International Maritime Dangerous Go- ods Code Международный морской перечень опасных грузов - MEZHDUNARODNIY MORSKOY PERECHEN' OPASNIKH GRUZOV. Rather popular are lexical -semantic transformations - offence - правонарушение PRAVONARUSHENIE, or damage to property - нанесение ущерба собственности - NANESENYE USHCHERBA SOBSTVENNOSTI (Osakve,2011).

All above mentioned may be considered as general peculiarities or general methods of translation of legal texts, which are in abundance: acts, directives, codes, treaties, licenses, contracts. But at the same time all of them have their own special features of translation techniques. We decided to devote this article to a more detailed description of contracts translation. 


\section{TRANSLATING CONTRACTS}

Professor Richard Wydick, the author of a popular book on legal writing gives the following definition: "We, lawyers, do not use plain English, we use eight words instead of two, we use secret phrases for expressing common ideas. In order to become accurate we became excessive, to become cautious, we became too verbose "(Baker,1992).

On the one hand, legal texts are not super difficult, as they do not contain words and expressions that cannot be translated; they have clear structure; they avoid emotionally colored vocabulary. All this makes the translation easier. On the other hand, the fact, that such texts are filled with elements of terminological system and professional language of law, complicates the process of translation.

It is easy to believe that high qualifications of a translator, and ideally, his or her law degree, may help to resolve these problems. Unfortunately, everything is much more difficult, and one's knowledge of terminology is not sufficient: there exist differences in how one and the same notion is transmitted in different legal systems, also one should consider cultural and language differences in established standards of business documentation in a foreign and the Russian languages.

G. Vermeer in 1970-80-s gave two approaches to the translation of the text of the Treaty of Guarantee as an example. He noted that if it is necessary that the Treaty of Guarantee in English should have legal power in the Federal Republic of Germany, it should be exchanged for a text constructed according to the rules of composing documents of such type in the Federal Republic of Germany. However, if someone in the Federal Republic of Germany would like to get acquainted with the rules of execution of the Treaty of Guarantee in the USA, the approach should be different: translation should reproduce all aspects of the content of the original with detailed clarification of fragments, difficult for understanding due to existing differences in legal systems of both countries (Sarcevic, 2000). It means that a legal document should not only be translated but its structure should also be adopted to the rules of the language of translation.

Translation of contracts is considered to be one of the most common and most complex types of translation. Contract is a formal writing which contains the agreement of parties with the terms and conditions and serves as a proof of the obligation (Dictionary of Contemporary English 2009). Translating contracts one should take into account not only legal terminology, but also the compliance of the translated text with the legal system of the country in which the contract was written. To achieve this, an adequate experience in the translation of legal terminology, as well as knowledge of the legislative system of the country in which the contract was written is needed. Translating a contract, one may face not only linguistic challenges, but also the particularities of the judicial systems of both countries. There exist many contract types: sales and purchase agreements; supply contracts; power supply contracts; real-estate property contracts; real property contracts; service agreements; rental and lease agreements, patent and know-how license agreements; deeds of gift; articles of association and others.

Contract (lat. contractus) is known to be a business document presenting an agreement approved and signed by two or more parts. Legal contracts are made in writing. When striking a deal, standard contracts are widely used. Standard contracts are not a must. Some articles can be altered and supplemented. There exists a proper set of items which are of the greatest importance in any contract: number of a contract; place and date of signing; names of the Sides signing the contract; subject of the contract; quality of goods; price; destination; delivery 
time; requirements for packing and marking; payment terms; conditions of submission and acceptance of goods; transport conditions; warranty conditions and sanctions; arbitration conditions; force majeure; judicial addresses of the Sides; signatures of the Seller and the Buyer. All appendices form an integral part of the contract ${ }^{2}$.

The language of contracts is agreed upon by both sides. It is evident that information and style are kept the same not depending on the language of textual varieties of contracts. Contracts are divided into administrative-managerial, financial-economical, advertising, scientific-technical, and artistic-publication contracts. Functional spheres of their circulation can be easily guessed from names of contract types in this classification, and are the subject of economic, rather than linguistic study ${ }^{3}$.

We can divide the peculiarities the language of contracts into lexical, stylistic and grammatical ones. Let us start with stylistic features of the language of contracts. The contracts should be - clear, concise, informative, logical, unemotional, possess clear division into chapters, paragraphs and points, often numbered.

From the lexical point of view the contracts usually include abbreviations, terms, clichés, sometimes foreign words (mainly from Latin, French). Let us present some examples:

The old-fashioned legal formulae such as HEREOF/THEREOF, HEREIN/THEREIN, HEREAFTER, HEREUNDER and related adverbs. These formal wordings are often used in legal language.

Also we may mention doublets, triplets, synonyms and quasi-synonyms, such as HAVE and HOLD, TERMS and CONDITIONS, FULL,TRUE and CORRECT or even TO ENABLE, ASSIST, PROMOTE and PROMULGATE. In making a decision which of the words to use a translator should bear in mind that in law each word may carry different meaning and therefore certain legal consequence (Popov, 2009).

As for grammatical side - they use definite syntactical models (but complicated and formal, also numerous paragraph divisions), including an abundance of verbals, passive constructions, prepositional phrases, modals and certain linkers. For example, among the most typical grammar problems we may notice:

- Pro-forms. The use of pro-forms belonging to different parts of speech (THE SAME, THE SAID, THE AFOREMENTIONED, THE FOREGOING, etc.) is one of the legal language. They are frequently used to refer to different parts of the document and suggest economical way of laying down the text. However they are defined as archaic and adding nothing to the normal equivalents like THE, THIS/THESE or THAT/THOSE.

- AND/OR. The formulation AND/OR is frequently used in legal documents, but can in certain situations lead to ambiguity. The reason for this is that the use of AND and OR together is often confusing, as each party may use the possibility to pick either AND or OR as the most favourable interpretation which is unacceptable as it undermines the principle of accuracy of the special text.

- Abundant use of passive forms. Statistics shows that approximately one quarter of all verbal constructions in legal English (including the grammar of contracts) are passive forms. For example: IF THE BILL IS PAID WITHIN

(NUMBER OF DAYS), THEN THERE WILL BE A $\%$

\footnotetext{
2 (https://elib.bsu.by/bitstream/123456789/230807/1/moreva_turlo_Lang_practice_2018_v2.pdf - 24.02.21)

3 (https://elib.bsu.by/bitstream/123456789/230807/1/moreva_turlo_Lang_practice_2018_v2.pdf - 22.02.21)
} 


\section{DISCOUNT OFF THE TOTAL AMOUNT DUE; PRICES MAY BE CHANGES BY SELLR TO SELLER'S PRICES CHARGES TO OTHER CUSTOMERS ON THE DATE OF DELIVERY.}

- The problems of choice between SHALL/WILL. In legal documents SHALL and WILL are usually distinguished - SHALL is often used for party obligations, but the contract policy is referred to thru WILL, which means that both words are found in one text in the English language, while in the Russian text the present tense is used to describe obligations, rights and duties of the contracting parties (Stepanova, Kiseleva,2014).

Syntactical challenges include complexity of syntax, conditional and hypothetical formulations, different types of negation mixed with other kinds of logical links within the text, repetition and abundant descriptive phrases, etc. (Adams, 2013).

Some researchers who specialize on legal translation state, that while translating contracts (as other legal documents) it is vital to distinguish form and content, as we need to adapt the functional part of the contract so as it correlates with the target language and preserve the content so as it remains true to the original. To perform this distinction one should separate formulaic language from the contract information. In this case the formulaic language usually includes: set formulas, clichés, structural elements (such as numbering), headings (of clauses, sections and the contract as such), certain sentence structures (Lynn, 2017). We fully agree with this idea, as the skill of distinguishing form and content not only will save time of the translator, but in general will make it easy to navigate and understand the original document.

It is obvious that each group of peculiarities of the language of contracts can contain certain difficulties in translation. For example, set formulas, clichés may cause problems as they evolve from legal system. If we change the system we may have to change the words used to express a function.

Sometimes contracts contain non-equivalent concepts which are not known in the legal system of the target language, which makes the translator responsible for getting their meaning across to the readers so that they can understand the contract. The main techniques being - term researching, which in its term includes: understanding the term in the source text -getting the meaning from the context, a dictionary, other similar texts, looking for translation, usually in bilingual resources, looking for definitions, usually in monolingual resources, comparing definitions and finally making a decision - to use one of the translations found, create a new one, or adapt one that was found, or even do further research. (Lynn, 2017).

Further on we would like to look at some of the difficult points in translation of contracts in more details. As it might have become obvious, that problems arising in the process of translation are varied and great in number. So, we will limit ourselves with illustrations of some difficulties in translating formulaic words and expressions, some of them being connected with differences with legal systems and legal text formation.

\subsection{Russian Counterpart of Contract}

In case of contracts we immediately face a problem: how to translate the very word "contract" into Russian: as it can be translated as KOHTPAKT [KONTRAKT], and as ДОГОВОР [DOGOVOR], and the English "agreement" can be translated as ДОГОВОР [DOGOVOR] and СОГЛАШЕНИЕ [SOGLASHENIE]. The thing is the Civil Code of 
the Russian Federation does not possess such a notion as KONTRACT [CONTRACT]. It allows to use the word KONTRAKT officially only in one case: when speaking about the federal and municipal commissioning, such as ГОСУДАРСТВЕННЫЙ КОНТРАКТ [GOSUDARSTVENNIY KONTRAKT] (state contract), МУНИЦИПАЛЬНЫЙ KOHTPAKT [MUNITSIPALNIY KONTRAKT] (city contract). This helps to resolve the first issue. However, if the document for translation is titled "agreement, we encounter the other dilemma DOGOVOR (agreement) or SOGLASHENIE (agreement)?

Table 1. Dogovor or Soglashenie?

\begin{tabular}{|c|c|c|}
\hline English & Russian & Transliteration \\
\hline Engineering Contract & $\begin{array}{l}\text { Договор подряда на } \\
\text { выполнение проектных } \\
\text { работ }\end{array}$ & $\begin{array}{l}\text { DOGOVOR PODRYADA NA } \\
\text { VIPOLNENIE PROEKTNIKH } \\
\text { RABOT }\end{array}$ \\
\hline Construction Contract & $\begin{array}{l}\text { Договор подряда на } \\
\text { строительство }\end{array}$ & $\begin{array}{l}\text { DOGOVOR PODRYADA NA } \\
\text { STROITEL'STVO }\end{array}$ \\
\hline $\begin{array}{l}\text { Confidentiality } \\
\text { Agreement }\end{array}$ & \begin{tabular}{|l|} 
Соглашение о \\
неразглашении/ \\
конфиденциальности \\
\end{tabular} & $\begin{array}{l}\text { SOGLASHENIE O } \\
\text { NERAZGLASHENII/ } \\
\text { KONFIDENSTIAL'NOSTI } \\
\end{array}$ \\
\hline Licensing Agreement & $\begin{array}{l}\text { Лицензионный договор/ } \\
\text { Лицензионное } \\
\text { соглашение }\end{array}$ & $\begin{array}{l}\text { LITSENZIONNIY DOGOVOR/ } \\
\text { LITSENZIONNOE } \\
\text { SOGLASHENIE }\end{array}$ \\
\hline Agency Agreement & Агентский договор & AGENTSKIY DOGOVOR \\
\hline
\end{tabular}

The same kind of problem is arisen when it is necessary to translate from Russian into English. In many cases contracts need supplementary agreements. There a translator should remember that there are different variants: if we translate the basic DOGOVOR as CONTRACT, then DOPOLNITELNOE SOGLSHENIE as supplementary AGREEMENT. But if the basic DOGOVOR is represented as AGREEMENT, then DOPOLNITELNOE SOGLSHENIE (supplementary agreement) will be translated as Addendum.

Any contract or agreement usually has exhibits of different kind, which are integral part of such contract or agreement. The thing is there are seven synonyms in English meaning 'a thing to be added's

Exhibit

Schedule

Annex

Appendix

ПРИЛОЖЕНИЕ (PRILOZHENIE)

Addendum

Supplement

Attachment

${ }^{4}$ https://www.dictionary.com/browse/addendum?s=t 
To make it worse national preferences exist, such as the Americans prefer 'Schedule' and 'Exhibit', while the British prefer 'Exhibit' and 'Annex', and Russians (when translating) commonly use 'Attachment'.

The real disaster occurs when the text simultaneously contains such cases as 'Attachment to Annex 1 of Exhibit 2 hereof'. Poor translators have to employ all their creativity as the Russian language does not contain so many synonyms to the word 'exhibit' (prilozhenie) as the English language has.

\begin{tabular}{|l|l|l|}
\hline $\begin{array}{l}\text { Attachment to Annex 1 of } \\
\text { Exhibit 2 hereof }\end{array}$ & $\begin{array}{l}\text { Дополнение к } \\
\text { Дополнительному } \\
\text { приложению 1 } \\
\text { Приложения 2 к } \\
\text { настоящему Договору }\end{array}$ \\
& $\begin{array}{l}\text { DOPOLNITEL'NOMU } \\
\text { PRILOZHENIYA 2 K } \\
\text { NASTOYASHCHEMU } \\
\text { DOGOVORU) }\end{array}$ \\
\hline
\end{tabular}

The only possible recommendation can be as follows: before you start translating you should scan the whole text and find out what terms are employed in the English text of a contract/ agreement, so as to select necessary equivalents. While translating from Russian into English we are free from such problems, as we have already mentioned, the Russian language possesses only two variants - “приложение” (PRILOZHENIE) and 'дополнение' (DOPOLNENIE), while English has seven ones.

The contracts drawn up by continental lawyers usually use the term "preamble", but only to refer to it. In the same contract text you will never find the word "preamble", usually preambles are unnamed. In contracts drafted by the UK or U.S. lawyers, you may find a plurality of terms, "PREAMBLE", "RECITALS" or "WHEREAS CLAUSES", less commonly "INTRODUCTION" or "BACKGROUND", it is usually marked and for all the variety of terms in Russian we have only one word to use in translation, namely 'ПРЕАМБУЛА' (PREAМВULA).

\section{2. "What Means my Name to You", or some notes about names}

Since we are talking about contracting documentation, there are parties to the contract and in most cases such parties are businesses which have their names. The company names are most often translated by transliteration or transcription, or a mixture of these methods. The only exception, when a company has a registered name in Russian and English, which any translator should check at the official website of the company. Therefore, the plant "Zvezda" does not turn into a plant STAR, and "Krasny treugolnik" into RED TRIANGLE, which are literal translations of these businesses. Often the translators prefer to leave the names in the Russian text of the contract in English, and it seems reasonable, and it is allowed by the local laws.

The other thing to remember is that according to the rules of the Russian language the name of the company is written in quotes, and even if you leave the name of the company in English, it shall be in quotation marks, e.g. Компания "Shell" (company) and in English, on the contrary, the quotes disappear, because according to the rules of the English language names are written without quotes "ГАЗПРОМ" = GAZPROM.

If the name is written in capital letters, then during translation it remains in capital letters. 
The abbreviations denoting the legal form of companies: ПAO, AO, OOO, or abbreviations Ltd, PLC, LLC, LC in English, Gmbh for German companies, S.p.A for Italian companies, etc. are transliterated or kept in the original language. The thing is the business forms of Russia do not fully coincide with business forms of other countries in legal terms. By translating the business form of any entity you turn a company of one jurisdiction into a company of another. The abbreviations of business forms is not only a part of the company name, but also a marker of its national affiliation. If potential partners want to find the company in the registry, and naturally in Russian, they will have to break their minds, which means PJSC specified by you instead of ПAO (PAO) or LLC instead of OOO. Thus, the authoritative sources, including the English courts, give the abbreviations of Russian businesses in transliteration. So, the business names should be transliterated into Russian in quotation marks with the foreign name in brackets, and be guided by the registration documents, and in the absence of such documents - transliterate by the rules. For example,

Original

United Systems, Inc.

Shell, LP

LUKOIL Overseas, Gmbh

ПАО «Газпром»

ПАО «Лукойл»

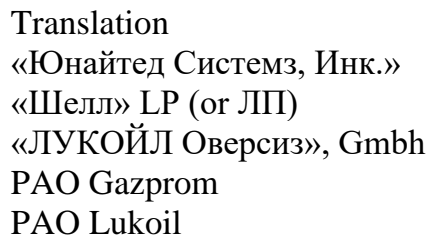

It is worth mentioning, that in English the abbreviation of the business form is written after the name of a company and remains in the same place in translation and vice versa for Russian companies.

The translation is necessary if the business form is given in full form

\section{Original}

Общество с ограниченной

ответственностью

Публичное акционерное общество

Акционерное общество
Translation

Limited Liabilities Company

Public Limited Company

Public Company/ Join Stock Company

\subsection{Translate or Not Translate, or how to DEAL With AdDRESSES AND NUMERALS}

All postal addresses in the contract shall be transliterated while keeping the foreign variant in parentheses.

Original

TECHNIP ITALY S.p.A, a company organized under the laws of Italy, and having a registered office at V.le Castello della Magliana, 68 - 00148 Rome, Italy
Translation

«ТЕКНИП ИТАЛИЯ» С.П.А, компания, зарегистрированная в соответствии с законодательством Италии, юридический адрес: В. Ле Кастелло делла Маглиана, 68-00148, Рим, Италия (V.le Castello della Magliana, 68 - 00148 Rome, Italy) 
The English 'having a registered office' or 'having a principal place of business at' shall be rendered as 'юридический адрес' (YURIDICHESKY ADRES [legal address]) or 'адрес регистрации' (ADRES REGISTRATSI [registration], and here the law failed to provide a clear answer to a translator. The RF Civil Code does not define a legal address, but there is a registration address. On the other hand, there are a number of regulatory documents that use the term legal address.

It would seem that it should not be difficult to translate figures. It wasn't there! Although the numbers themselves do not change, the format of their designation is undergoing some changes. Thus, in English, thousands should be distinguished by commas, and decimal fraction BY dots. In Russian, thousands are distinguished by spaces, and decimal fractions by commas.

$$
\$ 4,567.42=4567,42 \text { долларов США }
$$

In English numerals are stated at words first and then in figures in parentheses, in Russian it is vice versa.

Orginal

shall remain in force twelve (12) years

for a period not exceeding ninety $(\mathbf{9 0})$ business days

As you see, a translator has to remember a lot of 'minor' things when translating a contract, though these requirements stay true and for other kinds of translation, not only legal.

\section{CONTRACT DESIGN AND TRANSLATION}

Very often contracts in two languages are executed in two columns mirroring each other. Then there are no changes in the design when translating. Referred to:

\section{CONFIDENTIALITY AGREEMENT СОГЛАШЕНИЕ O КОНФИДЕНЦИАЛЬНОСТИ}

This AGREEMENT dated and effective the day $10^{\text {th }}$ of December, 2016 (hereinafter referred to as the "EFFECTIVE DATE")

\section{BY AND BETWEEN}

TECHNIP ITALY S.p.A, a company incorporated under the laws of Italy and having an office at V.le Castello della Magliana, 68 - 00148 Rome, Italy (hereinafter referred to as the "DISCLOSING PARTY"),

on the one hand,
Translation действительны в течение 12 (двенадцати) лет не более 90 (девяносто) рабочих дней
Настоящее СОГЛАШЕНИЕ датированное и вступающее в силу 10 декабря 2016 года (именуемая в дальнейшем «ДАТА ВСТУПЛЕНИЯ СОГЛАШЕНИЯ В СИЛУ») МЕЖДУ

«ТЕКНИП ИТАЛИЯ» S.p.А, компанией, зарегистрированной в соответствии с законодательством Италии, по адресу: Италия, Рим, В.ле Кастелло делла Маглиана, 68, 00148 (V.le Castello della Magliana, 68 - 00148 Rome, Italy) (именуемая в дальнейшем «РАЗГЛАШАЮЩАЯ СТОРОНА»), с одной стороны 
AND PAO GAZPROM, a company incorporated under the laws of the Russian Federation and having an office at 25, ul Krasnogo Oktyabrya, St. Petersburg, Russia, 199000 (ул. Красного Октября, 25, СанктПетербург, Россия, 199000) (hereinafter referred to as the "RECEIVING PARTY"), on the other hand, (hereinafter collectively referred to as the "PARTIES") и ПАО «ГАЗПРОМ», компанией, зарегистрированной в соответствии с законодательством Российской Федерации по адресу: ул. Красного Октября, 25, Санкт-Петербург, Россия, 199000 (именуемая в дальнейшем «ПОЛУЧАЮЩАЯ СТОРОНА»)

с другой стороны,

(в дальнейшем совместно именуемыми «СТОРОНЫ»)

Now let compare the execution of the same contract as two separate copies

\section{CONFIDENTIALITY AGREEMENT}

THIS AGREEMENT dated and effective the day $10^{\text {th }}$ of December, 2016 (hereinafter referred to as the "EFFECTIVE DATE")

\section{BY AND BETWEEN}

TECHNIP ITALY S.p.A, a company incorporated under the laws of Italy and having an office at V.le Castello della Magliana, 68 - 00148 Rome, Italy, on the one hand,

AND

PAO GAZPROM, a company incorporated under the laws of the Russian Federation and having an office at 25, ul Krasnogo Oktyabrya, St. Petersburg, Russia (ул. Красного Октября, 25, Санкт-Петербург, Россия, 199000), (hereinafter referred to as the "RECEIVING PARTY"), on the other hand, hereinafter collectively referred to as the "PARTIES"

\section{СОГЛАШЕНИЕ О КОНФИДЕНЦИАЛЬНОСТИ}

г. Санкт-Петербург

$\ll 10 »$ декабря_2016 года

«ТЕКНИП ИТАЛИЯ» S.p.А, компания, зарегистрированная в соответствии с законодательством Италии, по адресу: Италия, Рим, В.ле Кастелло делла Маглиана, 68, 00148 (V.le Castello della Magliana, 68 - 00148 Rome, Italy), (именуемая в дальнейшем «РАЗГЛАШАЮЩАЯ СТОРОНА») с одной стороны и ПАО «ГАЗПРОМ», компания, зарегистрированная в соответствии с законодательством Российской Федерации по адресу: ул. Красного Октября, 25, Санкт-Петербург, Россия, 199000 (именуемая в дальнейшем «ПОЛУЧАЮЩАЯ СТОРОНА»), совместно именуемые «Стороны» 
Please note that when executing the contract in Russian, the date and place of signing are specified on the upper left and right sides, respectively, and in English, the place of signing is specified at the end of the contract, and the date is written in the first line. The other question usually asked by future translators 'but what about the phrase hereinafter referred to as the "EFFECTIVE DATE"), which is omitted in our example. It will be written at the end of the contract, as is customary in Russian practice or as a separate article or will appear in the "Definitions" section, which is found in most contracts. See the example, when it is provided in Article Definitions of a contract:

\section{EFFECTIVE DATE}

EFFECTIVE DATE of the CONTRACT shall be the date of its signing by the PARTIES.

\section{ДАТА ВСТУПЛЕНИЯ ДОГОВОРА В СИЛУ}

Дата подписания настоящего договора
СТОРОНАМИ является ДАТОЙ
ВСТУПЛЕНИЯ ДОГОВОРА В СИЛУ.

\section{CONCLUSION}

The translation of legal texts cannot be done without regarding legal-cultural concepts and differences between legal systems. The level of equivalence of the terms depends on the extent of relatedness of the legal systems and not on that of the languages involved. Translators should not only possess general knowledge of legal terminology, they should also be well versed in statutory requirements and the legal intricacies of foreign cultural and legal systems (Katford,1978).

The text depends on cultural peculiarities and mentality of the nation, the distinctive features of its law system, which may lead to the situation when the idea of the text in the original language will not correspond to the idea of the text in the translation language even in the case of absolutely word-for-word interpretation, all the above mentioned proving the vital importance of studying socio-linguistic and socio-cultural aspects of translation.

But alongside with cultural and legal differences we should mention pure linguistic problems, as for example, problems with translation which are connected with polysemantic structure of some terms, absence of concept in either language, dependence of the meaning of the term on the context, idiomatic expressions, historically established traditions in legal text formation.

In general we may say, that out of the above mentioned difficulties, for the translator experiencing problems in translating legal texts, the core one is that the translation language lacks verbal constructions which can adequately render the terms of the original language (Proshina, 2008).

Dr Šarčević describes the legal translation as "not just a translation, but a translation from one legal system into another legal system" (Sarcevic, 2000). Certainly there are ways out: comprehensive full dictionaries, glossaries, databases comparing forms of legal documents in various countries, but the most effective and easiest way is that the translator should use all possibilities to enrich their vocabulary studying possible lexical equivalents to words and phrases, idiomatic expressions and the most widely used clichés. 


\section{REFERENCES}

Adams K. A. A Manual of Style for Legal Drafting (3d ed.). - American Bar Association, Chicago Publishing Association, 2013

Alekseeva L.M. Translatable and untranslatable writers// actual problems of German, Roman and Russian languages studies [Alekseeva L. M. Perevodimie i neperevodimie pisateli//aktual'nie problemi germanistiki, romanistiki i russistiki: mater.yezhegod. mezhgunarod.konf.] Ekaterinburg, 7 fevralya 2014. Ch.I Ekaterinburg: Ural. Gos. Ped. Int, 2014 pp.125-134

Alimov, V.V. Legal translation. Practical course. English language. [Alimov V.V. Yuridicheskiy perevod. Prakticheskiy kurs. Angliyskiy yazik.]M.: KomKniga, 2005. $-160 \mathrm{p}$

Baker, M. Other Words: a Coursebook on Translation, Routledge, London, 1992

Barkhudarov L.S. Language and translation. [Barkhudarov L.S. Yazik i perevod], M., 1975. $240 \mathrm{p}$.

Bazilev V.N., Sorokin Y.A. Studies in Interpretive translation [Bazilev V.N., Sorokin Y.A. Interpretativnoe perevodovedenie] Ulianovsk, UlGU,2000.134 p.

Dictionary of Contemporary English 2009

Fedorov K.M. Basics of general theory of translation. [Fedorov.K.M. Osnovi obshchey teorii perevoda] M.: Filologia Tri.2002. 416 p.

Hansen Gyde, Translation Errors, In L. Van Doorslaer \& Y. Gambier (eds). Handbook of Translation Studies (HTS). Amsterdam/Philadelphia: John Benjamins Publishing Company. 385-388., 2017

Harvey, M. What's so Special about Legal Translation? Meta, 47 (2), 177-185. 2002. https://doi.org/10.7202/008007ar

Karjo Clara Herlina Problems in Translating Legal English Text into Indonesian Arab World English Journal 6(2):352-364DOI: 10.24093/awej/vol6no2.27. 2016

Katford J C. A Linguistic Theory of Translation, Oxford University Press, 1978

Komissarov V.N. Modern translation studies [Komissarov V.N. Sovremennoye perevodovedenie] M., 2002. 424 p.

Komissarov, V.N. Theory of Translation (linguistic aspects) [Komissarov V. N. Teoria perevoda (lingvisticheskie aspekti)]- M.: Visshaya shkola, 1990. - 253 s.

Levitan K.M. Legal Translation: basics of theory and practice.[Levitan K.M. Yuridicheskiy perevod:osnovi teorii i practiki] M.: Ekaterinburg,2015.352 p.

Levitsky R. To the principle of functional adequacy of translation [Levitsky R. O printsipe funktsionalnoy adekvatnosti perevoda] Sopostavitelnoye yazikoznanye. 1984, IX. 3. p75

Lynn B. Systematic approach to translating contract into English. Beta version 2.0, 2017. roblunn@legalspaintrans.com

Malakhova A, Difficulties of Legal Translation. In Young Scientist USA, Vol. 2, p. 139. Auburn, WA: Lulu Press. 2015

Nida E. Towards a Science of Translating/ E. Nida - Leiden, 1964.- 331 p .

Nida, E. A., C. R. Taber. (2004). Theory and Practice of Translation. Shanghai: Shanghai Foreign Language Education Press, p12

Osakve K. Canons of correct legal translation: thoughts of a specialist in comparative civil studies on the example of comparative civil studies [Osakve K. Kanoni 
gramotnogo yuridicheskogo perevoda: razmishlenya komparativista-tsivilista na primere sravnitelnoy tsivilistiki// Pravo i upravlenye XXI c.] 2011. № 2. pp. 61-65

Pankratova E.A. Peculiarities of inter-cultural communication of law specialists// Languages of professional communication. [Pankratova E.A. Osobennosti mezhkulturnoi kommunikatsii spetsialistov yuridicheskgo profilya// yaziki professional'noy kommunikatsii: mater.mezhdunarod.naych.konf./ otv.red.E.I. Golovanova] Cheluabinsk:CHGAKI,2003.351 p.

Popov E.B. Translation in the sphere of contract law [Popov. E.V. Perevod v sfere dogovornogo prava]. Orenburg: OI MGJuA, 2009

Proshina Z.G. Theory of translation (from English to Russian and from Russian to English). Coursebook in English [Proshina Z. G. Teoria perevoda s angliiskogo yazika na russkiy i s russkogo yazika na angliiskiy. Uchebnik na angl. yaz.] . - Vladivostok: Far East University Publishing House, 2008.

Retsker Y.I. Tutorial on translation from English into Russian [Retsker Y.I. Posobiue po perevodu s angliyskogo yazika na russkiy] M.:Prosveshchenye,1982.159 p.

Sarcevic, S New Approach to Legal Translation. The Hague: Kluwer Law International, 2000

Schneidereit, G. Legal Language as a Special Language: Structural Features of English Legal Language, GRIN Verlag Gmbh, 2004

Shveitser A.D. Equivalency and adequacy//Communicative invariant of translation in texts of different jenres [Shveitser A.D. Ekvivalentnost' i adekvatnost'// Kommunikativniy invariant perevoda $\mathrm{v}$ tekstakh razlichnikh zhanrov]: sb.nauch.tr.M. MGPIIYA, 1989 pp.52-58.

Stepanova V.V., Kiseleva L.A. Challenges in translating commercial agreements.[ Stepanova V.V., Kiseleva L.A. Slozhnosti perevoda kommercheskikh soglasheniy] Vestnik RUDN,seria Russkiy i inostranniye yaziki i metodika ikh prepodavaniya,2014. № 3 pp. 87- 94

Vedernikova O.N. Linguistic errors with grave consequences, or problems of translation of international legal acts // Second All-Russian Derzhavin Readings (Moscow, November 910, 2006) [Vedernikova O.N. Lingvisticheskiye oshibki s tyazhkimi posledstviyami, ili problemi perevoda mezhdunarodnikh aktov// Vtoriue Vserossiyskiue Derzhavenskiye chtenua (Moskva, nouabr' 9-10,2006)]. Moscow: RPA, Ministry of Justice of Russia, 2007. p. 10-11.

Vermeer Reiss K., H.J. Grundlegung Einer Allgemeinen Translationstheorie. Tubingen, 1984

Weston, M. Problems and Principals in Legal Translation, The Incorporated Linguist. Autumn, Vol 22, No:4, 1983

Wydick Richard C., Sloan Amy E. Plain English for Lawyers, sixth edition academic press Durham, North Carolina, 2016 